\title{
GEOMETRIC MODELS FOR LATERITIC SOIL STABILIZED WITH CEMENT AND BAGASSE ASH
}

\author{
U. N. Okonkwo ${ }^{1,}$, J. C. Agunwamba ${ }^{2}$ and U. I. Iro ${ }^{3}$ \\ 1,3, DEPT. OF CiVIL ENGR., MichaEl OKPARA UNIVERSITY OF AGRICUltURE UMUdiKE, UMUAHIA, ABIA STATE, NIGERIA. \\ 2, DePARTMENT OF Civil ENGINEERING, UNIVERSiTy OF NigeRIA, NSUKKA. ENUGU STATE, NIGERIA \\ E-mail addresses: ${ }^{1}$ ugochukwuokonkwo75@gmail.com, ${ }^{2}$ nwambaagu@yahoo.com, 3 uzoarmstrong@gmail.com
}

\begin{abstract}
Agricultural and environmental demands for natural aggregates coupled with frequent increases in the price of cement and other binders have consequently escalated the cost of construction, rehabilitation and maintenance of road works. Soil stabilization emerges as an attractive option for providing low-cost roads. Bagasse-ash is an agricultural material obtained after squeezing out the sweet juice in sugarcane and incinerating the fibrous residue to ash. This residue that would have constituted an environmental problem during disposal and handling could be used as a supplement or partial replacement for cement in the cement-bound soil when converted to ash. Thus this study attempted to investigate into the effects of bagasse ash on compaction and strength characteristics of cementstabilized lateritic soil and also to develop geometric models. The compaction, California bearing ratio, unconfined compressive strength and durability tests were carried out on the cement-stabilized soil. Constant cement contents of $2 \%, 4 \%, 6 \%$ and $8 \%$ with variations of bagasse ash from $0 \%$ to $20 \%$ at $2 \%$ intervals and all percentages used were by the weight of dry soil. The multiple regression and the least square approach was used to develop geometric equations which was made less rigorous with Minitab statistical software. The three geometric equations developed covered the relationships of cost of bagasse ash content, optimum moisture content, cement content, California bearing ratio and unconfined compressive strength at 7 days. It was observed that optimum moisture content increased progressively while maximum dry density reduced with increase in bagasse ash content. Also the increase in cement content increased both the optimum moisture content and maximum dry density. In addition, all the strength properties were increased with increase in bagasse ash content and chemistry responsible was also presented. Thus bagasse ash was confirmed to be a good admixture in soil stabilization for road-work. The models were calibrated and verified; and were found to be dependable.
\end{abstract}

Keywords: Bagasse-Ash, Cement, Lateritic Soil, Compaction and Strength Characteristics, Geometric Models.

\section{INTRODUCTION}

Soils are formed by weathering of rocks due to mechanical disintegration or chemical decomposition. When a rock surface gets exposed to the atmosphere for an appreciable time, it disintegrates or decomposes into small particles and thus the soils are formed. If soil is formed and it stays just above the parent rock, it is referred to as residual soil. Residual soils have a gradual transition from relatively fine material near the surface to large fragments of stones at greater depth [1]. Lateritic soils are typical example of residual soil because they are sedentary during formation while they undergo leaching of lighter minerals like silica and consequently enriching of heavier minerals (sesquioxides) like iron oxide and Alumina. The major part of Nigeria is underlain by basement complex rocks, the weathering of which had produced lateritic materials spread over most part of the area. It is virtually impossible to execute any construction work in Nigeria without the use of lateritic soil because they are virtually non-swelling [2].

Agricultural and environmental demands for natural aggregates coupled with frequent increases in the price of cement and other binders have consequently escalated the cost of construction, rehabilitation and maintenance of road works. Soil stabilization with bagasse ash emerges as an attractive option for 
providing low-cost roads because the soils are locally available and relatively cheap. This would be one way of actualizing the dreams of the Federal government of Nigeria in scouting for readily cheap construction materials. Internationally, the World Bank equally has been spending substantial amounts of money on research aimed at harnessing industrial waste products for further usage.

Bagasse-ash is an agricultural material obtained after squeezing out the sweet juice in sugarcane and incinerating the fibrous residue to ash. This residue has constituted a waste especially in the sugarcane markets and sugar factories which therefore requires proper handling. Bagasse ash has been characterized [3] and found to be rich in silica $\left(\mathrm{SiO}_{2}\right)$ up to $72.8 \%$ thus it is a good pozzolana. This particular lateritic soil had been worked on by [4] and was characterized to be A-6(2) in the [5] rating system. The soil was regarded as being fairly good for road-work. Illite was found to be the major clay mineral present and is of medium plasticity. Another admixture and cement were used to treat the soil and it was observed that the strength properties of the stabilized soil increased but the cement content requirement was high. Therefore, in the ever increasing efforts in converting waste to wealth, bagasse ash could be used as a supplement or partial replacement for cement in order to reduce the cement content requirement which ultimately reduces the cost of construction and maintenance of roads.

Some researchers have attempted to examine the behaviours of soils with pozzolanic materials [6] and [7] while others when treated with bagasse ash. However, the chemistry and attributes behind its usefulness in soil stabilization had not been shown. Bagasse ash was used as a potential quartz replacement in red ceramic and an improvement was discovered in ceramic/ash properties up to sintering temperatures higher than $1000^{\circ} \mathrm{C}[8]$. The effect of up to $12 \%$ bagasse ash by weight of the dry soil on the geotechnical properties of deficient lateritic soil was studied [9]. It was concluded that bagasse ash cannot be used as a 'stand-alone' stabilizer but should be utilized as admixture in soil stabilization. A study the influence of compactive effort on bagasse ash with cement treated lateritic soil which showed increase in optimum moisture content (OMC) and decrease in maximum dry density (MDD) with increase in the percentage of bagasse ash and cement [10]. Bagasse ash was used as admixture in lime-stabilized black cotton soil and large quantity of lime was required to achieve sufficient stabilization [11]. The potential use of black cotton soil treated with bagasse ash for the attenuation of cationic contaminants in municipal solid waste leachate was looked at and higher bagasse ash content increased the sorption of the contaminant species [12]. Other works on improvement of geotechnical characteristics of soils using bagasse ash include [13], [14], [15] and [16]. All these have shown the promising potentials in bagasse ash as useful in soil stabilization. Most of these attempts had not included modeling however this work focused on developing geometric models to cover relationships between the constituents, compaction and strength characteristics of the stabilized matrix.

Model was referred to as an imitation of something on a smaller scale and also that mathematical model stands as a mathematical representation of a set of relationship between variables and parameters [17]. In other words, it is the act of constructing or fashioning a model of something or finding a relationship between variables or parameters. In case of an existing system, a model intends to improve on its performance, while it explores to identity the best structure/properties of a future system [18]. Because of limited resources, there is a need to be very conscious not to be wasteful. The process of mathematical modeling and prediction puts a check on how effective limited field data are put to use in decision-making. The trend of modeling is to collate existing records (data), establish relationships via mathematical equation(s), and calibrate the equation with experimental results and adopting such equation for forecasting and prediction. Prediction looks into the future for decision-making.

\section{MATERIALS AND METHODS}

The soil samples were collected from a lateritic soil deposit in Oboro, Ikwuano Local Government Area of Abia State in Nigeria. It was collected at a depth of not less than $150 \mathrm{~mm}$ at 15 different points of about $3 \mathrm{~m}$ apart using the method of disturbed sampling technique and was air-dried. The bagasse residue was collected from Panyam district, Mangu Local Government Area, Plateau State of Nigeria. It was incinerated into ash in a furnace with temperature of up to $500^{\circ} \mathrm{C}$ for about 2 hours after which it was allowed to cool and thoroughly ground. It was then sieved through $75 \mu \mathrm{m}$ sieve as required by [19]. The test specimens were prepared by first thoroughly mixing dry quantities of pulverized soil with bagasse ash and Portland cement in a mixing tray to obtain a 
uniform colour. Constant cement contents of $2 \%, 4 \%$, $6 \%$ and $8 \%$ with variations of bagasse ash from $0 \%$ to $20 \%$ at $2 \%$ intervals and all percentages used were by the weight of dry soil. The required amount of water which was determined from moisture- density relationships for stabilized-soil mixtures was then added to the mixture. The Standard Proctor mould was used for the compaction test in which 3 layers and 27 blows were given onto each layer with $2.5 \mathrm{Kg}$ rammer. The specimens from the Proctor mould were used as the unconfined compressive strength specimen and a correction factor of 1.04 was used on the results to conform to cylindrical specimens with a height/diameter ratio of 2:1or $150 \mathrm{~mm}$ cube specimens. The membrane curing and 7 days curing period was used for the test specimens. The California Bearing Ratio was modified so as to conform to the recommendation of [20] which stipulates that the specimens should be cured for six days unsoaked, immersed in water for 24 hours and allowed to drain for 15 minutes before testing. The durability tests were carried out as specified by [21] where two identical sets of unconfined compressive strength specimens were prepared both of which were cured in the normal manner at constant moisture content for 7 days. Then one set was immersed in water for 7 days whilst the other set continues to cure at constant moisture content. When both sets were 14 days old, they were tested and the strength of the set immersed in water was compared with the strength of the set cured at constant moisture content.

\section{FORMULATION OF MODELS}

The multiple regression approach was used to develop the geometric models. The cost of bagasse ash stands as the dependent variable while the other parameters of strength characteristics, cement content and optimum moisture content stand for the independent variables. Consider a regression model of the form;

$$
y=c x^{\mathrm{al}} \cdot z^{\mathrm{a} 2}
$$

Where; $x$ and $\mathrm{z}$ are the dependent variables; $\mathrm{c}, \mathrm{a}_{1}$ and $\mathrm{a}_{2}$ are constants.

Equation (1) can be linearized or transformed to multiple regression model by taking the logarithm of both sides:

$$
\log y=\log c+a_{1} \log x+a_{2} \log z
$$

Thus, the estimates of the coefficients, $c, a_{1}$ and $a_{2}$ can be obtained by setting

$$
\begin{gathered}
\log y=y_{1}, \log c=a_{0}, x_{1}=\log x \text { and } x_{2} \\
=\log z
\end{gathered}
$$

Therefore, equation (2) could be represented as: $\mathrm{y}_{1}=\mathrm{a}_{0}+\mathrm{a}_{1} x_{1}+\mathrm{a}_{2} x_{2}$

Equation (3) is a linear regression equation of $\mathrm{y}_{1}$ on $x_{1}$ and $x_{2}$. The dependent variable $\mathrm{y}_{1}$ varies partially due to variations in $x_{1}$ and $x_{2}$, respectively, the coefficients $\mathrm{a}_{1}$ and $\mathrm{a}_{2}$ represent partial regression coefficients of $\mathrm{y}_{1}$ on $x_{1}$ with $x_{2}$ held constant; $\mathrm{y}_{1}$ on $x_{2}$ with $x_{1}$ held constant; respectively. For a four dimensional space coordinate system, Equation (3) represents a hyperplane usually called a regression hyperplane.

Given $\mathrm{n}$ sets of measurements, $\left(\mathrm{y}_{1}, x_{11}, x_{21}, x_{31}\right) \ldots \ldots,\left(\mathrm{y}_{\mathrm{n}}\right.$, $\left.\mathrm{y}_{1 \mathrm{n},} x_{2 \mathrm{n}}, x_{3 \mathrm{n}}\right)$ the least square estimates of $\mathrm{a}_{0}, \mathrm{a}_{1}, \mathrm{a}_{2}$ and $\mathrm{a}_{3}$ can be obtained using equations:

$$
\begin{gathered}
a_{0} n+a_{1} \sum x_{1 i}+a_{2} \sum x_{2 i}+a_{3} \sum x_{3 i}=\sum y_{i} \\
a_{0} \sum x_{1 i}+a_{1} \sum x^{2}{ }_{1 i}+a_{2} \sum x_{2 i} x_{1 i}+a_{3} \sum x_{3 i} x_{1 i} \\
=\sum y_{i} x_{1 i} \\
a_{0} \sum x_{2 i}+a_{1} \sum x_{1 i} x_{2 i}+a_{2} \sum x^{2} 2_{i}+a_{3} \sum x_{3 i} x_{2 i} \\
=\sum y_{i} x_{2 i} \\
a_{0} \sum x_{3 i}+a_{1} \sum x_{1 i} x_{3 i} \\
+a_{2} \sum x_{2 i} x_{3 i}+a_{3} \sum x_{3 i} \ldots \\
=\sum y_{i} x_{3 i}
\end{gathered}
$$

However, the above Least Square operation could be made less rigorous by the use of statistical softwares that have been developed in the computation. Minitab Statistical software was used in this work.

Thus applying it to the compaction and strength characteristics as independent variables and cost of bagasse ash as dependent variable to form the equation which stands as the objective function;

$Z$ is the Cost of bagasse ash in Kobo, $M$ is the Optimum Moisture Content in percentage, $C$ is the California Bearing Ratio in Percentage, $H$ is the Unconfined Compressive Strength for 7 days curing period in $\mathrm{KN} / \mathrm{m}^{2}, E$ is the Cement content in percentage,

$$
\begin{gathered}
\log Z=a_{0}+a_{1} \log M+a_{2} \log C+a_{3} \log H \\
+a_{4} \log E
\end{gathered}
$$

Where $\mathrm{a}_{\mathrm{o}}, \mathrm{a}_{1}, \ldots . \mathrm{a}_{2}, \mathrm{a}_{3}$ anda $\mathrm{a}_{4}$ are constants.

Equation (8) could be transformed to:

$$
Z=10^{a 0} M^{a 1} C^{a 2} H^{a 3} E^{a 4}
$$

Similarly more geometric relationships could be formed from the parameters where unconfined compressive strength and cement content would stand as dependent variables and presented as follows:

$$
\begin{aligned}
& H=10^{a 5} M^{a 6} C^{a 7} E^{a 8} \\
& E=10^{a 9} M^{a 10} C^{a 11} H^{a 12}
\end{aligned}
$$


Table 1: Bagasse Ash Content and the Corresponding Attached Cost

\begin{tabular}{|c|c|c|c|c|c|c|c|c|c|c|c|}
\hline Bagasse Ash Content (\%) & 0 & 2 & 4 & 6 & 8 & 10 & 12 & 14 & 16 & 18 & 20 \\
\hline Cost (kobo) & 0 & 0.8 & 1.6 & 2.4 & 3.2 & 4.0 & 4.8 & 5.6 & 6.4 & 7.2 & 8.0 \\
\hline
\end{tabular}

\section{RESULTS AND DISCUSSION}

\subsection{Compaction Characteristics}

Table 2 showed the relationship between optimum moisture content and bagasse ash content at different cement contents. The Optimum Moisture Content increased progressively from $16.50 \%$ to $22.62 \%$, $17.90 \%$ to $23.54 \%, 18.24 \%$ to $24.44 \%$ and $20.39 \%$ to $25.31 \%$ at $2 \%, 4 \%, 6 \%$ and $8 \%$ cement contents respectively with addition of bagasse ash from $0 \%$ to $20 \%$.

Table 2: Variations of Optimum Moisture Content with Increase in Bagasse Ash Content at 2\%, 4\%, 6\% and 8\% Cement Contents

\begin{tabular}{lcccc}
\hline $\begin{array}{l}\text { Bagasse } \\
\text { Ash }\end{array}$ & \multicolumn{4}{c}{ Optimum Moisture Content (\%) } \\
\cline { 2 - 5 } $\begin{array}{l}\text { Content } \\
(\%)\end{array}$ & $2 \%$ Cement & $\begin{array}{c}4 \% \\
\text { Cement }\end{array}$ & $\begin{array}{c}6 \% \\
\text { Cement }\end{array}$ & $\begin{array}{c}8 \% \\
\text { Cement }\end{array}$ \\
\hline 0 & 16.50 & 17.90 & 18.24 & 20.39 \\
2 & 16.80 & 17.97 & 18.41 & 20.56 \\
4 & 17.71 & 18.30 & 18.91 & 21.24 \\
6 & 18.74 & 19.69 & 20.85 & 21.63 \\
8 & 19.58 & 20.48 & 21.66 & 22.08 \\
10 & 20.23 & 21.29 & 22.39 & 22.63 \\
12 & 20.81 & 21.71 & 22.71 & 23.05 \\
14 & 21.32 & 22.17 & 23.29 & 23.95 \\
16 & 22.01 & 22.85 & 23.75 & 24.69 \\
18 & 22.22 & 23.21 & 24.23 & 25.02 \\
20 & 22.62 & 23.54 & 24.44 & 25.31 \\
\hline
\end{tabular}

Table 3: Variations of Maximum Dry Density with Increase in Bagasse Ash Content at 2\%, 4\%, 6\% and 8\% Cement Content

\begin{tabular}{lcccc}
\hline Bagasse & \multicolumn{4}{c}{ Maximum Dry Density $\left(\mathrm{Kg} / \mathrm{m}^{3}\right)$} \\
\cline { 2 - 5 } $\begin{array}{l}\text { Ash } \\
\text { Content } \\
(\%)\end{array}$ & $2 \%$ cement & $\begin{array}{c}4 \% \\
\text { cement }\end{array}$ & $6 \%$ cement & $\begin{array}{c}8 \% \\
\text { cement }\end{array}$ \\
\hline 0 & 1661 & 1777 & 1891 & 2199 \\
2 & 1634 & 1771 & 1875 & 2132 \\
4 & 1612 & 1759 & 1805 & 2084 \\
6 & 1584 & 1742 & 1783 & 2022 \\
8 & 1551 & 1708 & 1724 & 1996 \\
10 & 1533 & 1691 & 1702 & 1971 \\
12 & 1503 & 1671 & 1689 & 1954 \\
14 & 1489 & 1630 & 1644 & 1933 \\
16 & 1463 & 1602 & 1628 & 1877 \\
18 & 1441 & 1591 & 1601 & 1846 \\
20 & 1422 & 1572 & 1586 & 1791 \\
\hline
\end{tabular}

These increments in optimum moisture content with increase in bagasse ash could be attributed to the increased amount of water required in the system to adequately lubricate all the particles in the soilcement and bagasse ash mixture. Therefore the optimum moisture content continuously increased with increase in bagasse ash content. It was also observed from the results in Table 2 that the increase in cement content in the mixture also increased the optimum moisture content of the mixture. The reason for this could be that the increase in cement contents steps-up the hydration reaction of cement and consequently increases the demand for water in the system. This would result to the increase in optimum moisture content.

Table 3 showed the relationship between maximum dry density and bagasse ash content at different cement contents. In the corollary, the maximum dry density reduced from $1661 \mathrm{Kg} / \mathrm{m}^{3}$ to $1422 \mathrm{Kg} / \mathrm{m}^{3}$, $1777 \mathrm{Kg} / \mathrm{m}^{3}$ to $1572 \mathrm{Kg} / \mathrm{m}^{3}, 1891 \mathrm{Kg} / \mathrm{m}^{3}$ to 1586 $\mathrm{Kg} / \mathrm{m}^{3}$ and $2199 \mathrm{Kg} / \mathrm{m}^{3}$ to $1791 \mathrm{Kg} / \mathrm{m}^{3}$ at $2 \%, 4 \%, 6 \%$ and $8 \%$ cement contents respectively with addition of bagasse ash from $0 \%$ to $20 \%$. This could be as a result of the partial replacement of the soil of higher specific gravity (2.75) with bagasse ash of lower specific gravity (2.25). Also considering the reaction between cement, bagasse ash and fine fractions of the soil in which they form clusters that occupied larger spaces and invariably increasing their volume with decreasing the maximum dry density. In some cases the clusters formed were not strongly bound and the disruption was necessary in order to achieve higher level of compaction at a given compaction energy, part of the compactive effort was lost in dislodging the weak bonds which results to reduced density. As the cement content increased, the bonds became stronger and the soil-cement-bagasse ash clusters behave more like coarse aggregates thus became more amenable to compaction. This resulted in the increase in maximum dry density with increase in cement content.

\subsection{Strength Characteristics}

The California bearing ratio, the unconfined compressive strength and the durability tests are the strength properties of the stabilized matrix. Table 4 presented the relationship between California bearing ratio and bagasse ash content. The California bearing ratio at $2 \%$ cement content increased from $22.30 \%$ at 
$0 \%$ bagasse ash content to attain a value of $25.13 \%$ at $8 \%$ bagasse ash content and in a similar trend the California bearing ratio at $4 \%$ cement content rose from $57.99 \%$ at $0 \%$ bagasse ash content to attain its peak at $163.59 \%$ at $16 \%$ bagasse ash content. While the California Bearing Ratio at 6\% and 8\% cement content increased continuously from $83.34 \%$ to $239.16 \%$ and from $147.16 \%$ to $276.30 \%$ respectively at the addition of bagasse ash from $0 \%$ to $20 \%$. Table 5 clearly showed that the unconfined compressive strength of $2 \%, 4 \%, 6 \%$ and $8 \%$ cement contents at 7 days, 14 days curing periods and 7 days curing + 7 days soaking all increased remarkably and consistently with the addition of bagasse ash from $0 \%$ to $20 \%$ bagasse ash content.

Table 4: Variations of California Bearing Ratio with Increase Bagasse Ash Content at 2\%, 4\%, 6\% and 8\% Cement Contents

\begin{tabular}{|c|c|c|c|c|}
\hline \multirow{2}{*}{$\begin{array}{l}\text { Bagasse } \\
\text { Ash } \\
\text { Content } \\
\text { (\%) }\end{array}$} & \multicolumn{4}{|c|}{ California Bearing Ratio (\%) } \\
\hline & $\begin{array}{c}2 \% \\
\text { Cement }\end{array}$ & $\begin{array}{c}4 \% \\
\text { Cement }\end{array}$ & $\begin{array}{c}6 \% \\
\text { Cement }\end{array}$ & $\begin{array}{c}8 \% \\
\text { Cement }\end{array}$ \\
\hline 0 & 22.30 & 57.99 & 83.34 & 147.16 \\
\hline 2 & 23.57 & 84.44 & 93.70 & 175.12 \\
\hline 4 & 25.42 & 85.20 & 104.94 & 196.37 \\
\hline 6 & 26.48 & 93.04 & 117.07 & 209.09 \\
\hline 8 & 25.13 & 109.13 & 123.68 & 221.03 \\
\hline 10 & 25.11 & 121.03 & 135.59 & 230.24 \\
\hline 12 & 24.98 & 135.19 & 176.12 & 242.05 \\
\hline 14 & 24.92 & 152.10 & 196.50 & 251.31 \\
\hline 16 & 24.70 & 163.59 & 207.26 & 265.30 \\
\hline 18 & 24.31 & 161.38 & 220.08 & 271.80 \\
\hline 20 & 24.23 & 160.96 & 239.16 & 276.30 \\
\hline
\end{tabular}

This trend of the improvement in the strength properties of the stabilized matrix could be better explained with the chemistry of the chemical compounds (Tri-Calcium Silicate, Di-Calcium Silicate, Tri-Calcium Aluminate and Tetra-Calcium Alumino Ferrite) in cement as shown in equations (12) through (15) respectively.

$$
\begin{aligned}
& \mathrm{Ca}_{2} \mathrm{SiO}_{4}+2 \mathrm{H}_{2} \mathrm{O} \rightarrow \mathrm{CaO} \cdot \mathrm{SiO}_{2} \cdot \mathrm{H}_{2} \mathrm{O}+\mathrm{Ca}(\mathrm{OH})_{2} \\
& \mathrm{Ca}_{3} \mathrm{SiO}_{5}+3 \mathrm{H}_{2} \mathrm{O} \rightarrow \mathrm{CaO} \cdot \mathrm{SiO}_{2} \cdot \mathrm{H}_{2} \mathrm{O}+2 \mathrm{Ca}(\mathrm{OH})_{2} \\
& \mathrm{Ca}_{3} \mathrm{Al}_{2} \mathrm{O}_{6}+3 \mathrm{H}_{2} \mathrm{O} \rightarrow \mathrm{CaO} \cdot \mathrm{Al}_{2} \mathrm{O}_{3} \cdot \mathrm{H}_{2} \mathrm{O}+2 \mathrm{Ca}(\mathrm{OH})_{2} \cdot \\
& \mathrm{Ca}_{4} \mathrm{Al}_{2} \mathrm{Fe}_{2} \mathrm{O}_{10}+4 \mathrm{H} \mathrm{H}_{2} \mathrm{O} \rightarrow \\
& \quad \mathrm{CaO} \cdot \mathrm{Al}_{2} \mathrm{O}_{3} \cdot \mathrm{Fe}_{2} \mathrm{O}_{3} \cdot \mathrm{H}_{2} \mathrm{O}+3 \mathrm{Ca}(\mathrm{OH})_{2}
\end{aligned}
$$

The calcium silicate hydrates and calcium hydroxide have been described as dominant products of hydration which are produced at the early stage of hydration mainly by the selective hydration of dicalcium silicate and tricalcium silicate. Between the two foregoing, the tricalcium silicate reacts first and dominates the reaction within first few days of hydration [23], [24], [25], [26] and [27]. Tricalcium silicates was described as the most important phase of cement and the calcium silicate hydrate gel resulting from this reaction is reported to be principally responsible for the mechanical properties of hydrated cement [24] and [25]. A common product of the four equations for the hydration of cement Equations (12) through (15) is calcium hydroxide.

The high amount silica provided by bagasse ash reacted with the excess amounts of calcium hydroxide produced after hydration reaction of cement compound to further produce additional calcium silicate hydrates which is very vital for strength development. The additional amount of calcium silicate hydrates produced will depend on the amount

\begin{tabular}{|c|c|c|c|c|c|c|c|c|c|c|c|c|}
\hline \multirow{3}{*}{$\begin{array}{l}\text { Bagasse } \\
\text { AshCont } \\
\text { ent (\%) }\end{array}$} & \multicolumn{12}{|c|}{ Unconfined Compressive Strength $\left(\mathrm{KN} / \mathrm{m}^{2}\right)$} \\
\hline & \multicolumn{3}{|c|}{ 2\% Cement } & \multicolumn{3}{|c|}{$4 \%$ Cement } & \multicolumn{3}{|c|}{$6 \%$ Cement } & \multicolumn{3}{|c|}{ 8\% Cement } \\
\hline & $7 d$ & $14 d$ & $\begin{array}{c}7 d+7 \\
s k\end{array}$ & $7 d$ & $14 d$ & $\begin{array}{c}7 \mathrm{~d}+7 \\
\mathrm{sk}\end{array}$ & $7 d$ & $14 d$ & $\begin{array}{c}7 \mathrm{~d}+7 \\
\mathrm{sk}\end{array}$ & $7 d$ & $14 d$ & $7 d+7 s k$ \\
\hline 0 & 213 & 248 & 225 & 419 & 513 & 498 & 549 & 864 & 740 & 942 & 1210 & 1008 \\
\hline 2 & 228 & 262 & 243 & 454 & 549 & 510 & 642 & 924 & 876 & 998 & 1241 & 1136 \\
\hline 4 & 248 & 289 & 254 & 492 & 589 & 555 & 683 & 1014 & 903 & 1049 & 1320 & 1231 \\
\hline 6 & 273 & 328 & 288 & 534 & 647 & 583 & 801 & 1066 & 951 & 1087 & 1492 & 1292 \\
\hline 8 & 292 & 375 & 313 & 575 & 698 & 601 & 854 & 1110 & 978 & 1132 & 1662 & 1431 \\
\hline 10 & 308 & 399 & 327 & 613 & 749 & 643 & 907 & 1228 & 1005 & 1180 & 1776 & 1536 \\
\hline 12 & 321 & 428 & 365 & 642 & 788 & 693 & 941 & 1259 & 1053 & 1221 & 1833 & 1615 \\
\hline 14 & 335 & 421 & 386 & 665 & 863 & 728 & 985 & 1312 & 1112 & 1298 & 1868 & 1679 \\
\hline 16 & 349 & 426 & 397 & 697 & 902 & 795 & 1018 & 1373 & 1152 & 1366 & 1905 & 1763 \\
\hline 18 & 353 & 442 & 411 & 717 & 915 & 804 & 1057 & 1390 & 1201 & 1396 & 1945 & 1801 \\
\hline 20 & 364 & 459 & 418 & 733 & 948 & 856 & 1073 & 1435 & 1272 & 1424 & 1986 & 1877 \\
\hline
\end{tabular}
of calcium hydroxide given out from the hydration reaction of cement compounds.

Table 5: Variations of Unconfined Compressive Strength and Age with Increase inBagasse Ash Content at 2\%, 4\%, 6\% and $8 \%$ Cement Contents. 
The improved strength of the resulting stabilized matrix could be attributed to the amounts of calcium silicate hydrates that were produced as shown in the proposed Equations (16) through (18). The following are the proposed equations for the reaction between silica from bagasse ash and calcium hydroxide, the common product of hydration reaction of cement compounds:

$$
\begin{aligned}
& \mathrm{Ca}(\mathrm{OH})_{2 \mathrm{SiO}_{2}} \rightarrow \mathrm{CaO} \cdot \mathrm{SiO}_{2} \cdot \mathrm{H}_{2} \mathrm{O} \\
& 2 \mathrm{Ca}(\mathrm{OH})_{2}+\mathrm{SiO}_{2} \rightarrow 2 \mathrm{CaO} \cdot \mathrm{SiO}_{2} \cdot \mathrm{H}_{2} \mathrm{O} \\
& 3 \mathrm{Ca}(\mathrm{OH})_{2}+\mathrm{SiO}_{2} \rightarrow 3 \mathrm{CaO} \cdot \mathrm{SiO}_{2} \mathrm{H}_{2} \mathrm{O}
\end{aligned}
$$

\section{REGRESSION MODELS}

The procedure of formulation of multiple regression models as earlier discussed was used and Minitab statistical software was also used to make it less rigorous. The outputs were shown as follows:

\subsection{Regression Analysis 1}

Relationship of Cost of Bagasse Ash, Optimum Moisture Content, Cement Content, California Bearing Ratio and Unconfined Compressive Strength at 7 days. The regression equation is $\log \mathrm{Z}=-8.73+5.71 \log \mathrm{M}-1.64 \log \mathrm{E}+0.203 \log \mathrm{C}+$ $0.824 \log \mathrm{H}$

\begin{tabular}{lccccc} 
Predictor & \multicolumn{2}{c}{ CoefStDev } & $T$ & \multicolumn{2}{l}{$\mathrm{P}$} \\
Constant & -8.7348 & 0.7468 & -11.70 & 0.000 \\
$\log \mathrm{P}$ & 5.712 & 1.201 & 4.75 & 0.000 \\
$\log \mathrm{E}$ & -1.6370 & 0.5364 & -3.05 & 0.004 \\
$\log \mathrm{C}$ & 0.2031 & 0.1731 & 1.17 & 0.249 \\
$\operatorname{logS}$ & 0.8244 & 0.6387 & 1.29 & 0.205 \\
$\mathrm{~S}=0.1215$ & $\mathrm{R}-\mathrm{Sq}=85.8 \%$ & \multicolumn{2}{l}{$\mathrm{R}-\mathrm{Sq}(\mathrm{adj})=84.1 \%$}
\end{tabular}

\subsection{Analysis of Variance}

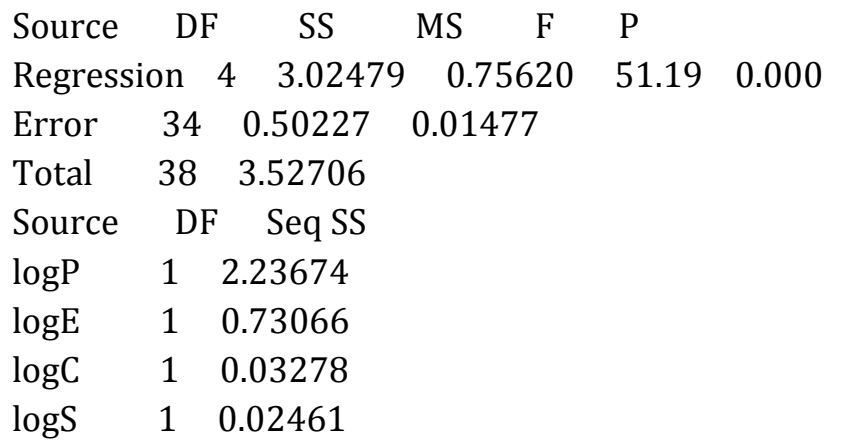

\subsection{Regression Analysis 2}

Relationship of Unconfined Compressive Strength at 7 days, Optimum Moisture Content, California Bearing Ratio and Cement Content.

The regression equation is:

\begin{tabular}{|c|c|c|c|c|}
\hline Predictor & CoefSt & Dev & $\mathrm{P}$ & \\
\hline Constant & 0.1033 & 0.1969 & 0.52 & 0.603 \\
\hline $\log \mathrm{P}$ & 1.5870 & 0.1707 & 9.30 & 0.000 \\
\hline $\log C$ & 0.05898 & 0.04472 & 1.32 & 0.196 \\
\hline $\log E$ & 0.74697 & 0.06491 & 11.51 & 0.000 \\
\hline
\end{tabular}
$\log \mathrm{H}=0.103+1.59 \log \mathrm{M}+0.0590 \log \mathrm{C}+0.747 \log \mathrm{E}$

\subsection{Analysis of Variance}

$\begin{array}{lcccccc}\text { Source } & \text { DF } & \text { SS } & \text { MS } & \text { F } & \text { P } & \\ \text { Regression } & 3 & 2.01665 & 0.67222 & 649.70 & 0.000 \\ \text { Error } & 35 & 0.03621 & 0.00103 & & \\ \text { Total } & 38 & 2.05287 & & & \\ \text { Source } & \text { DF } & \text { Seq SS } & & & \\ \log P & 1 & 0.95673 & & & \\ \log C & 1 & 0.92289 & & & \\ \log E & 1 & 0.13704 & & & \end{array}$

\subsection{Regression Analysis 3}

Relationship of Cement Content, Optimum Moisture Content, California Bearing Ratio and Unconfined Compressive Strength at 7 days

The regression equation is

$$
\begin{array}{lllll}
\log \mathrm{E}=0.027 & -1.88 & \log \mathrm{M}+ & 0.0697 & \log \mathrm{C}+1.06 \\
\text { Predictor } & \text { CoefStDev } & \mathrm{T} & \mathrm{P} \\
\text { Constant } & 0.0274 & 0.2353 & 0.12 & 0.908 \\
\log \mathrm{P} & -1.8797 & 0.2058 & -9.13 & 0.000 \\
\log \mathrm{C} & 0.06967 & 0.05326 & 1.31 & 0.199 \\
\log \mathrm{S} & 1.05892 & 0.09201 & 11.51 & 0.000 \\
\mathrm{~S}=0.03830 & \mathrm{R}-\mathrm{Sq}=97.4 \% & \mathrm{R}-\mathrm{Sq}(\mathrm{adj})=97.2 \%
\end{array}
$$

\subsection{Analysis of Variance}

$\begin{array}{lcccccc}\text { Source } & \text { DF } & \text { SS } & \text { MS } & \text { F } & \text { P } & \\ \text { Regression } & 3 & 1.92586 & 0.64195 & 437.67 & 0.000 \\ \text { Error } & 35 & 0.05134 & 0.00147 & & \\ \text { Total } & 38 & 1.97720 & & & \\ \text { Source } & \text { DF } & \text { Seq SS } & & & \\ \log P & 1 & 0.42451 & & & \\ \log C & 1 & 1.30708 & & & \\ \operatorname{logS} & 1 & 0.19427 & & & \end{array}$

The regression equation in analysis 1 represents the relationship of logarithmic values of cost of bagasse ash content as the dependent variable while logarithmic values of optimum moisture content, cement content, California bearing ratio and unconfined compressive strength at 7 days were the independent variables with 5.71, -1.64, 0.203 and 0.824 respectively as their coefficients. The square of coefficient of correlation R-sq and R-sq adjusted were $85.8 \%$ and $84.1 \%$ respectively. The P-values of 0.000 , $0.000,0.004,0.249$ and 0.205 represented the 
influence of the constant value, logarithmic values of optimum moisture content, cement content, California bearing ratio and the unconfined compressive strength at 7 days respectively on the output (cost of bagasse ash content) of the model. All the P-values are much less than 0.5 therefore they had high level of influence in the regression equation. The standard deviation ' $\mathrm{S}$ ' of the equation is 0.1215 which was quite low and consequently the model equation is dependable.

The regression equation in analysis 2 represents the relationship of logarithmic values of unconfined compressive strength at 7 days as the dependent variable while logarithmic values of optimum moisture content, California bearing ratio and cement content were the independent variables with 1.59 , 0.0590 and 0.747 respectively as their coefficients. The square of coefficient of correlation R-sq and R-sq adjusted were $98.2 \%$ and $98.1 \%$ respectively. The Pvalues of $0.603,0.000,0.196$ and 0.000 represented the level at which the constant value, logarithmic values of optimum moisture content, California bearing ratio and cement content respectively influence the dependent variable. All the P-values were much less than 0.5 except that of the constant which is of less importance in the equation. Therefore the variables had high level of influence in the regression equation. The standard deviation ' $S$ ' of the equation was 0.03217 which was quite low and consequently the model equation is dependable.

The regression equation in analysis 3 represents the relationship of logarithmic values of cement content as the dependent variable while logarithmic values of optimum moisture content, California bearing ratio and unconfined compressive strength at 7 days were the independent variables with $-1.88,0.0697,1.06$ respectively as their coefficient. The square of coefficient of correlation R-sq and R-sq adjusted were $97.4 \%$ and $97.2 \%$ respectively. The P-values of 0.908 , $0.000,0.199$ and 0.000 were the level of influence of the constant value, logarithmic values of optimum moisture content, California bearing ratio and cement content respectively on the dependent variable. All the
P-values were much less than 0.5 except that of the constant that is very high (almost 1 ). This is even very satisfactory because the constant had less importance in the equation. Thus, the variables had high level of influence in the regression equation. The standard deviation ' $\mathrm{S}$ ' of the equation was 0.03830 which was quite low and consequently the model equation is dependable.

\section{CALIBRATION AND VERIFICATION OF MODELS}

The regression models were verified using the experimental results. The last two observations at $8 \%$ cement content ( $18 \%$ and $20 \%$ bagasse ash) were not used for the regression model. Afterwards, they were used to compare the predicted results to test the conformity of the models' predicted results to the actual values of the properties of the stabilized soil. The results were presented in Table 6.1.

Table 6 showed the comparison of predicted results with experimental results. It was clearly shown that the two presented results were very close to each other. These indicated that the three geometric models could predict reliable results.

\section{CONCLUSIONS}

After the study of the effects of bagasse ash on properties of cement-stabilized lateritic soil, the following conclusions were drawn;

i. The optimum moisture content increased with increase in bagasse ash content.

ii. The optimum moisture content increased with increase in cement content.

iii. The maximum dry density reduced with increase in bagasse ash content.

iv. The maximum dry density increased with increase in cement content.

v. The strength properties of the stabilized matrix (California bearing ratio, unconfined compressive strength and durability) all increased with increase in bagasse ash content.

vi. In view of the foregoing, it would appear that bagasse ash is confirmed to be a good admixture in soil stabilization with cement.

Table 6: Comparison of Predicted Results to Experimental Results

\begin{tabular}{c|c|c|c|c|}
\hline \multirow{2}{*}{ Regression Analysis } & \multicolumn{2}{|c|}{ Predicted } & \multicolumn{2}{c|}{ Experimental } \\
\cline { 2 - 5 } & $18 \%$ & $20 \%$ & $18 \%$ & $20 \%$ \\
\hline Model 1 & $18.05 \%$ & $19.67 \%$ & $18 \%$ & $20 \%$ \\
Model 2 & $1394.78 \mathrm{KN} / \mathrm{m}^{2}$ & $1421.96 \mathrm{KN} / \mathrm{m}^{2}$ & $1396 \mathrm{KN} / \mathrm{m}^{2}$ & $1424 \mathrm{KN} / \mathrm{m}^{2}$ \\
Model 3 & $7.97 \%$ & $7.98 \%$ & $8 \%$ & $8 \%$ \\
\hline
\end{tabular}


vii Geometric relationships of cost of bagasse ash, optimum moisture contents, cement contents, California bearing ratio and unconfined compressive strengths at 7 days were found to be dependable.

\section{ACKNOWLEDGEMENTS}

The authors sincerely wish to express profound gratitude to GEOTECHNICAL ENGINEERING SERVICES LIMITED, Calabar, Nigeria and her technical staff for their support during the laboratory work

\section{REFERENCES}

[1] Arora, K. R. 'Soil Mechanics and Foundation Engineering" Seventh Edition, Standard Publishers Distributors, Delhi, India, (2008).

[2] Osinubi, K. J. "Permeability of Lime Treated Lateritic Soil Journal of Transportation Engineering, American Society of Civil Engineers, Vol. 124, Number 5, pp465-469. (1998).

[3] Okonkwo, U. N. and Agunwamba, J. C." Characterization of Bagasse Ash and Lateritic Soil for Low-Cost Roads Construction in Nigeria" Nigerian Journal of Soil and Environmental Research, Ahmadu Bello University Zaria, Vol. 12, , pp154-159. (2014).

[4] Okonkwo, U. N.; Odiong I. C. and Akpabio, E. E. "The Effects of Egg Shell Ash on Strength Properties of Cement-Stabilized Lateritic soil", International Journal of Sustainable Construction Engineering and Technology, University Tun Hussein Onn Malaysia and Concrete Society of Malaysia, Vol. 3, Number 1, , pp18-25 (2012).

[5] AASHTO "Standard Specifications for Transportation Materials and Methods of Sampling and Testing" American Association of State Highway and Transportation Officials, Washington D. C., (1986).

[6] Murana, A. A., Olowosulu, A. T. and Ahiwa S. "Performance of MetaKaolin as Partial Replacement of Cement in Hot Mix Ashphalt" Nigerian Journal of Technology, Vol. 33, Number 3, , pp387-393. (2014).

[7] Ikponmwosa, E., Fapohunda, C. and Ehikhuenmen, S. "Suitability of Polyvinyl Waste Powder as Partial Replacement for Cement in Concrete Production" Nigerian Journal of Technology, Vol. 33, Number 4, , pp387-393. (2014).

[8] Silvio, R. T., Agda, E. S., Gleyson, T. A. S., Angel, F. V. P. and Alvaro, G. M.: "Sugarcane Bagasse Ash as a Potential Quartz Replacement in Red Ceramic" Journal of the American Ceramic Society, Vol. 91, Number 6, 2008, pp1883-(1887).
[9] Osinubi, K. J.; Bafyau, V. and Eberemu, A. O. "Bagasse Ash Stabilization of Lateritic Soil" Earth and Environmental Science Appropriate Technologies for Environmental Protection in Developing World, Book chapter, Springer Link Science and Business Media:, pp271-280. (2009a).

[10] Mohammed, A. M. "Influence of Compactive Effort on Bagasse Ash with Cement Treated Lateritic Soil" Leonardo Electronic Journal of Practices and Technologies, Issue 10: pp. 79-92. (2007).

[11] Osinubi, K. J.; Ijimdiya T. S. and Nmadu, I. "Lime Stabilization of Black Cotton Soil Using Bagasse Ash as Admixture" Advanced Materials Research, Switzerland, 62-64, pp. 3-10. (2009b,)

[12] Ijimdiya, T. S. and Osinubi, K. J. "Attenuative Capacity of Compacted Black Cotton Soil Treated with Bagasse Ash." Electronic Journal of Geotechnical Engineering, Issue 16, , pp 420-429. (2011).

[13] Osinubi, K. J. and Stephen, T. A. "Economic Utilization of an Agro-Industrial Waste-Bagasse Ash" Proceedings of the $4^{\text {th }}$ Nigerian Materials Congress (NIMACON, 2005), Zaria, Nigeria. pp. 3640. (2005)

[14] Osinubi, K. J. and Stephen, T. A. "Influence of Compactive Efforts on Bagasse Ash Treated Black Cotton Soil" Nigerian Journal of Soil and Environmental Research, Ahmadu Bello University Zaria, Vol. 7:, pp 92-101. (2007).

[15] Osinubi, K. J. and Ijimdiya, T. S. "Laboratory Investigation of Dessication Characteristics of Black Cotton Soil Treated with Bagasse Ash" Proceedings of Bi-monthly Meetings/ Workshop, Organised by Zaria Chapter of Materials Society of Nigeria; pp 61-68. (2009).

[16] Ijimdiya, T. S. "Evaluation of Bagasse Ash Treated Black Cotton Soil As Hydraulic Barrier in Waste Containment Systems." Unpublished Ph.D Dissertation, Ahmadu Bello University Zaria, Nigeria. (2010).

[17] Nwaogazie, I. L. "Probability and Statistics for Science and Engineering Practice" University of Port Harcourt Press, Nigeria, (2006).

[18] Agunwamba, J. C. "Engineering Mathematical Analysis." De-Adroit Innovation, Enugu. (2007).

[19] BS 12 "Specification for Portland Cement." British Standard Institute, London. (1991).

[20] Nigerian General Specification "Bridges and Roadworks" Vol.11, Federal Ministry of Works, Lagos. (1997).

[21] BS 1924 "Methods of Test for Stabilized Soils." British Standard Institute, London. (1990). 
[22] Okonkwo, U. N. "Optimization of Bagasse Ash Content in Cement Stabilized Lateritic Soil." Unpublished Ph.D. Dissertation Submitted to Department of Civil Engineering, University of Nigeria Nsukka. (2015).

[23] Neville, A. M. "Properties of Concrete." Fourth Edition, Second Indian Reprint, Pearson Education, India. (2003).

[24] Scrivener, K. L. "Backscattered Electron Imaging of Cementitious Microstructures: Understanding and Quantification." Cement and Concrete Composites, Vol.26, Number 8, , pp 935-945. (2004).
[25] Escalante-Garcia, J. I. and Sharp, J. I. "The Chemical Composition and Microstructure of Hydration Products in Blended Cements." Cement and Concrete Composites, Vol. 26, Number 8, pp 967976. (2004).

[26] Kjellesen, K. O. and Justnes, H. 'Revisiting the Microstructure of Hydrated TriCalcium Silicate- a Comparison to Portland Cement." Cement and Concrete Composites, Vol. 26, Number 8, , pp 947956. (2004).

[27] Shetty, M. S. "Concrete Technology: Theory and Practice" S. Chand \& Company Limited, New Delhi, India. (2005). 